\title{
Comparing the Efficacy of Chemical Cautery to Cryosurgery on CD4+ Status of HIV Patients with Condyloma Acuminata
}

\section{Prasetyadi Mawardi ${ }^{1}$ \\ Bobby Febrianto' \\ Danu Yuliarto (D) \\ Tatar Sumandjar ${ }^{2}$}

'Department of Dermatology and Venereology, Faculty of Medicine, Sebelas Maret University/Dr. Moewardi General Hospital, Surakarta, Central Java, Indonesia; ${ }^{2}$ Voluntary Counseling and Testing Clinic/Department of Internal Medicine, Faculty of Medicine, Sebelas Maret University/Dr. Moewardi General Hospital, Surakarta, Central Java, Indonesia
Correspondence: Prasetyadi Mawardi Department of Dermatology and Venereology, Faculty of Medicine, Sebelas Maret University/Dr. Moewardi General Hospital, Surakarta, Central Java, Indonesia Tel +628I2297502II

Email prasetyadi_m@staff.uns.ac.id
Introduction: Condyloma acuminata (CA) is one of the sexually transmitted infections caused by human papillomavirus (HPV). Condyloma acuminata patients are usually coinfected with human immunodeficiency virus (HIV), particularly those with low CD4+ levels. Chemical cautery and cryosurgery are therapeutic modalities for CA, aiming to remove lesions and prevent recurrence, especially in patients with HIV.

Objective: To compare the efficacy of chemical cautery to cryosurgery on CD4+ status of HIV patients with CA.

Methods: A cross-sectional retrospective study was conducted in patients with CA visiting the Dermatology and Venereology outpatient clinic and the voluntary counseling and testing (VCT) clinic of Dr. Moewardi Hospital Surakarta, Indonesia from January 2018 to December 2020. The data were taken from the medical records of patients. These subjects were grouped into CA with HIV and without HIV. The data were statistically analyzed with $t$-tests followed by multivariate regression tests, and a p-value of $<0.05$ was considered significant.

Results: Seventy-eight patients with CA were included in the study, comprising 41 subjects with HIV infection and 37 subjects without HIV infection. The subjects were predominantly male $(68 \%)$. Of all the subjects, $70.5 \%$ received chemical cautery, and the remaining had cryosurgery. Multivariate regression tests obtained no significant differences in CD4+ levels between chemical cautery and cryosurgery $(\mathrm{p}=0.138$ vs $\mathrm{p}=0.907)$.

Conclusion: Either chemical cautery or cryosurgery is effective in improving the clinical condition of patients with CA. Although chemical cautery results in a higher level of CD4+ than cryosurgery, statistically both therapies have no significant difference regarding CD4+ status.

Keywords: CD4+, chemical cautery, condyloma acuminata, cryosurgery, HIV

\section{Introduction}

Condyloma acuminata (CA), or genital warts, is one of the sexually transmitted infections (STIs) resulting from human papillomavirus (HPV), primarily types 6 and 11, which manifests in the form of cutaneous tissue hyperplasia or mucosal hyperplasia. It has been estimated that the incidence of CA is around 160-289 cases in 100,000 individuals per year worldwide. ${ }^{1}$ Based on the data taken from Dr. Moewardi General Hospital, Surakarta, Indonesia, there were $13.7 \%$ cases of anogenital warts. ${ }^{2}$ In general, CA treatment aims to eradicate lesions and prevent their recurrence with minimal side effects. Condyloma acuminata can be treated pharmacologically with imiquimod, podophyllotoxin, trichloroacetic acid (TCA), 
and sinecatechins from green tea leaves and nonpharmacologically by electrosurgical excision, frozen surgery, infrared coagulation, or laser ablation. ${ }^{3}$

Coinfection of human immunodeficiency virus (HIV) and $\mathrm{CA}$ is commonly observed in patients with low CD4+ levels. Patients with HIV experience declining levels of Langerhans cells, CD4+, macrophage, and natural killer (NK) cells. The changing of the local immune system and decreasing of T-cell memory in circulation functioning to fight HPV infection facilitates the occurrence of CA in tissues. ${ }^{4}$ Conley et al. stated that patients with HIV infection are more susceptible to vulvovaginal as well as perianal CA and intraepithelial neoplasia. Meanwhile, Massad et al. reported that $60 \%$ of women with HIV-1 infection and $80 \%$ of individuals are more likely to have CA recurrence after receiving therapy during the first year of treatment. ${ }^{5,6}$ Theoretically, HPV infection triggers immunosuppression by depleting $\mathrm{CD} 4+$ level, so that appropriate management is required to elevate $\mathrm{CD} 4+$ level in order to achieve optimum outcome. Moreover, in giving therapy we must take into account its effectiveness and cost according to Indonesian health insurance policy. Hence we conducted this study to compare the efficacy of chemical cautery using TCA to cryosurgery (liquid nitrogen) on patients with low CD4+ levels with HIV infection and CA.

\section{Methods}

\section{Study Design}

A hospital-based, cross-sectional retrospective study was conducted using medical record data of patients visiting the Dermatology and Venereology outpatient clinic and Voluntary Counseling and Testing (VCT) clinic of Dr. Moewardi Hospital Surakarta, Central Java, Indonesia from 1 January 2018 to 31 December 2020.

\section{Study Population and Data Collection}

All patients diagnosed with CA based on physical examinations and biopsy were included in the study. The International Classification of Diseases revision 10 (ICD10) was used to determine the diagnosis based on medical record. Patients who were diagnosed with HIV infection and CA evidenced by laboratory examination based on CD4+ level were also enrolled in this study. Condyloma acuminata patients with HIV infection who were not registered on the VCT clinic medical record, had passed away, or continued their therapy in other hospitals were excluded from the study. We only included patients who agreed to participate in this study by signing the informed consent prior to study protocol. In addition, we included patients aged between 15 and 18 whose parents allowed their children to join the study by signing the informed consent form.

\section{Patient Management}

After signing informed consent forms, all patients received either cryosurgery using liquid nitrogen or chemical cautery with TCA $80 \%$ solution based on ICD-9 for its procedure. In line with the 2019 European guideline for the management of anogenital warts, we performed the therapy session weekly until the lesions disappeared. We used the spray technique using cryogen for cryosurgery. These patients received two cycles of freeze-thaw on each lesion using a nozzle $\mathrm{C}(0.06 \mathrm{~mm})$ for the lesion freezing procedure. The spraying was done continuously, limited to $1 \mathrm{~mm}$ from the edge of the lesion until it looked like frosting, in which the distance between the nozzle and the lesion's surface was $0.5-1 \mathrm{~cm}$. Chemical cautery was performed with TCA $80 \%$ solution applied twice every single session of therapy by using a cotton tipped applicator on the lesion until it looked like frosting. Each study subject underwent CD4+ level measurement twice during the study period, before starting the therapy procedure and after he/she had completed the therapy.

\section{Statistical Analysis}

Categorical variables were described as numbers and percentages and continuous variables were expressed as medians. The demographic characteristic data taken from medical records of patients were sex, age, occupation, sex orientation, lesion site, therapy type, and treatment duration. $T$-tests were used to evaluate the relation between CA without HIV infection and CA with HIV infection. Multivariate regression analysis was used to analyze the difference in the efficacy of the two therapy procedures on CD4+ based on treatment duration. All data were statistically analyzed with SPSS version 23 and a p-value of 0.05 was considered significant.

\section{Ethical Issues}

This study was approved by the Health Research Ethical Committee of Dr. Moewardi Hospital/Faculty of Medicine, of Sebelas Maret University, Surakarta, Central Java, Indonesia (440/I/HREC/2021). The study was conducted in accordance with the Declaration of Helsinki. Patients' confidentiality was assured. 
Table I Demographic Characteristics of CA Patients in the Study

\begin{tabular}{|c|c|c|c|}
\hline Variables & $\begin{array}{l}\text { Condyloma Acuminata without HIV } \\
\text { Infection, } n=37 \text { (\%); Mean } \pm \text { SD }\end{array}$ & $\begin{array}{l}\text { Condyloma Acuminata with HIV } \\
\text { Infection, } n=4 \text { I (\%); Mean } \pm \text { SD }\end{array}$ & p-value \\
\hline $\begin{array}{l}\text { Sex } \\
\qquad \text { Male } \\
\text { Female }\end{array}$ & $\begin{array}{l}17(21.8) \\
20(25.6)\end{array}$ & $\begin{array}{c}36(46.2) \\
5(6.4)\end{array}$ & $<0.010 * *$ \\
\hline $\begin{array}{l}\text { Age (years old) } \\
\begin{array}{l}15-19 \\
20-24 \\
25-29 \\
30-34 \\
35-39 \\
40-44 \\
45-49 \\
50-54 \\
\geq 55\end{array}\end{array}$ & $\begin{array}{c}30 \pm 13.05 \\
1(1.3) \\
6(7.7) \\
8(10.3) \\
7(9.0) \\
6(7.7) \\
2(2.6) \\
1(1.3) \\
2(2.6) \\
4(5.1)\end{array}$ & $\begin{array}{c}26 \pm 7.23 \\
3(3.8) \\
14(17.9) \\
12(15.4) \\
5(6.4) \\
4(5.1) \\
1(1.3) \\
2(2.6) \\
0(0.0) \\
0(0.0)\end{array}$ & 0.140 \\
\hline $\begin{array}{l}\text { Occupation } \\
\text { High school student } \\
\text { University student } \\
\text { Housewife } \\
\text { Employee } \\
\text { Entrepreneur } \\
\text { Teacher } \\
\text { Civil servant }\end{array}$ & $\begin{array}{c}1(1.3) \\
3(3.8) \\
7(9.0) \\
16(20.5) \\
6(7.7) \\
2(2.6) \\
2(2.6)\end{array}$ & $\begin{array}{c}3(3.8) \\
7(9.0) \\
1(1.3) \\
20(25.6) \\
10(12.8) \\
0(0.0) \\
0(0.0)\end{array}$ & $0.050^{*}$ \\
\hline $\begin{array}{l}\text { Sexual orientation } \\
\text { Heterosexual } \\
\text { Homosexual } \\
\text { Bisexual }\end{array}$ & $\begin{array}{c}29(37.2) \\
4(5.1) \\
4(5.1)\end{array}$ & $\begin{array}{c}13(16.7) \\
20(25.6) \\
8(10.3)\end{array}$ & $<0.010^{* * *}$ \\
\hline $\begin{array}{l}\text { Lesion site } \\
\text { Genital } \\
\text { Anorectal } \\
\text { Genital and anorectal }\end{array}$ & $\begin{array}{c}26(33.3) \\
6(7.7) \\
5(6.4)\end{array}$ & $\begin{array}{c}\text { II }(14.1) \\
24(30.8) \\
6(7.7)\end{array}$ & $<0.010^{* *}$ \\
\hline $\begin{array}{l}\text { Treatment } \\
\text { Chemical cautery } \\
\text { Cryosurgery }\end{array}$ & $\begin{array}{c}29(37.2) \\
8(10.3)\end{array}$ & $\begin{array}{l}26(33.3) \\
15(19.2)\end{array}$ & 0.148 \\
\hline $\begin{array}{l}\text { Treatment duration (week) } \\
\text { Chemical cautery } \\
\text { Cryosurgery }\end{array}$ & $\begin{array}{l}15.72 \pm 13.26 \\
22.50 \pm 7.98\end{array}$ & $\begin{array}{c}31.84 \pm 34.23 \\
32 \pm 23.51\end{array}$ & 0.592 \\
\hline
\end{tabular}

Notes: *Statistical significant with $p<0.05$. **Statistical significant with $p<0.01$. Abbreviation: HIV, human immunodeficiency virus.

\section{Results}

During the study period we obtained 78 patients meeting our inclusion criteria, comprising $37 \mathrm{CA}$ patients without HIV infection (47.43\%) and $41 \mathrm{CA}$ patients with HIV infection $(52.57 \%)$. Males $(n=36)$ were more dominant than females $(n=5)$ in the CA with HIV group. The mean ages of CA patients without HIV and with HIV were $30 \pm$ 13.05 years and $26 \pm 7.23$ years, respectively. The significant difference between the two groups observed in the demographic characteristics of the subjects was occupation $(\mathrm{p}=0.05)$. The mean treatment durations of chemical cautery and cryosurgery were $23.34 \pm 26.45$ weeks and $28.69 \pm 19.84$ weeks, respectively (Table 1).

Of the total $41 \mathrm{CA}$ patients with HIV infection, 18 visited VCT of other hospitals, so we excluded them; the remaining 23 patients underwent $\mathrm{CD} 4+$ level examination. 
Table 2 Comparison of Treatment Efficacy on CD4+ Level in CA Patients with HIV Infection

\begin{tabular}{|l|c|c|c|}
\hline Treatment & CD4+ & F & Sig. \\
\hline Chemical cautery $(24 \pm 23.07)$ & Pre & 1.192 & 0.438 \\
& Post & 2.788 & 0.138 \\
& Range & 2.673 & 0.148 \\
\hline Cryosurgery $(20 \pm 23.64)$ & Pre & 0.756 & 0.649 \\
& Post & 0.292 & 0.907 \\
& Range & 0.462 & 0.807 \\
\hline
\end{tabular}

The mean of initial CD4+ level was $112 \pm 164.760$, while the mean CD4+ level at the end of the treatment was $182 \pm$ 279.281. Multivariate regression analysis revealed no significant difference regarding CD4+ level in patients receiving either chemical cautery or cryosurgery (Table 2).

\section{Discussion}

Condyloma acuminata is one of the STI types caused by HPV; it is highly infectious. The estimated incidence of CA around the globe is 200 cases in 100,000 individuals. It is more prevalent in males than females, with a ratio of 1:0.7. This is similar to our finding, as $68 \%$ of our study subjects were male. Based on age group, CA mostly affects people aged between 16 and 25 years old; its incidence is 700 cases per 100,000 population. ${ }^{7}$ Patel et al. reported that females are more concerned about their reproductive health so that they regularly visit their gynecologists; hence, the prevalence of CA is lower in this population than in males. They also found that heterosexual males usually deny having a history of $\mathrm{CA}$, thus many cases were too late to manage or mistreated. ${ }^{8}$ A study by Puspawati et al. revealed that CA commonly affected aldolescents $(47.31 \%)$ as they are in their productive age and usually sexually active. In this study the highest incidence of CA was observed in subjects aged 2029 years old $(28.2 \%){ }^{9}$

A previous study on CA by de Peder et al. found the highest incidence of $\mathrm{CA}$ in the heterosexual group (36.7\%), while Piketty et al. reported its incidence in the homosexual group was $85-93 \% .{ }^{10,11}$ We also obtained the highest number of CA without HIV in the heterosexual group (37.2\%) and in the homosexual group (25.6\%) for CA with HIV. The predilection sites of CA are genital and extra-genital areas. There is a transition zone in anal mucosa, which is located right over the dentate line. In this zone squamous epithelium changes into columnar epithelium, in which most of the big cells are immature so that micro-trauma and HPV transmission often occur in

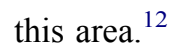

In general, $\mathrm{CA}$ treatment aims to remove lesions and prevent recurrence. Some modalities used to treat $\mathrm{CA}$ are chemical cautery using TCA solution and cryosurgery with liquid nitrogen. Sharma et al., when comparing cryosurgery mono-therapy with combined therapy using podophyllin $25 \%$ solution as a single therapy, showed that single therapy using cryosurgery resulted in a higher cure rate and lower recurrent rate than combined therapy $(89 \%$; $7 \%$ vs $85 \%$; 11.5\%). ${ }^{13}$ Moreover, Fathi and Tsoukas discovered that TCA $80-90 \%$ as a mono-therapy for CA yielded a cure rate of $70-80 \%$, with a recurrent rate of $36 \%$. ${ }^{14}$ However, based on duration of treatment, chemical cautery was a shorter process than cryosurgery in both groups (23.34 \pm 26.45 weeks vs $28.69 \pm 19.84$ weeks).

To date there has been no report comparing chemical cautery to cryosurgery regarding their effect on $\mathrm{CD}^{+}$level of CA patients with HIV infection. This study finding revealed that statistically there was no significant difference between those two treatments in term of $\mathrm{CD}^{+}$level, although subjects receiving chemical cautery had higher CD4+ levels than cryosurgery subjects. An experimental study by Blossom et al. conducted on mice receiving TCA for 32 weeks demonstrated an increase in CD4+ production. This increase results from the activation of CD62L, an adhesion molecule in lymphocyte, whereas TCA will activate $\mathrm{CD} 62 \mathrm{~L}$ or a naive phenotype to differentiate from $\mathrm{CD}^{2} \mathrm{~L}^{\mathrm{h} 1}$ in lymphocyte T-cells which then produce CD4 $+{ }^{15}$ An in vivo study by Newell et al. demonstrated that inhibition in T-cell receptor alpha and beta (TCRaß)-CD3 will inhibit CD4+ to bind with major histocompatibility complex class II (MHC II), thus apoptosis does not occur. $^{16}$ An in vivo and in vitro study by Barber et al. reported that $\mathrm{CD} 4+$ and $\mathrm{CD} 8+$ antigens can inhibit protein kinase enzyme p5 $^{\text {lck }}$ which phosphorylates CD3 complex leading to the activation of effector T-cells. ${ }^{17}$ Study findings of McCabe et al. stated that inhibition in CD95 and Fas pathway, which in nature is a death-inducing signaling complex (DISC), will prevent lymphocyte T-cell. $^{18}$

As we know, decreasing of CD4+ level can be triggered by HPV infection. A study by Cao et al. showed patients with $\mathrm{CA}$ had lower $\mathrm{CD} 4+$ level, $\mathrm{CD} 4+/ \mathrm{CD} 8+$ ratio, and higher $\mathrm{CD} 8+$ level compared to healthy subjects. ${ }^{19}$ The secretion of various cytokines in CA patients, such as interleukin (IL) 2, IL-12, and interferon gamma (IFN- $\gamma$ ), are markedly decreased. By contrast, the expression of tumor 
necrosis factor alpha (TNF- $\alpha$ ), IL-4, and IL10 in patients with CA are significantly increased compared to those of the control group. This condition shows that the HPV antigenspecific function switches T-helper (Th)1 to Th2 immune response which indicates suppressed immunity. ${ }^{20,21}$ Moreover, overexpression of $\mathrm{T}$ regulatory cells may contribute to immunosuppression in local lesions of HPV promoting production of IL-10 and transforming growth factor beta (TGF- $\beta$ ) without causing abnormal changes in CD4+ T lymphocyte level. ${ }^{22}$

This study is limited by small sample size and single center. Our subjects were mostly males, and chemical cautery was more commonly used than cryosurgery. However, this has a strength in that we analyzed sexual orientation including heterosexual, homosexual, and bisexual patients. Further study is needed involving large subjects and a more heterogeneous population.

\section{Conclusion}

Condyloma acuminata is a common STI which is usually accompanied by HIV infection. Chemical cautery and cryosurgery are effective in clinical improvement of patients with $\mathrm{CA}$, but none of them showed a significant effect on CD4+ level of CA patients with HIV infection.

\section{Acknowledgments}

We thank Tatar Sumandjar, MD, Ph.D for collecting several references. Additionally, we appreciate the support from hospitals administrations and data collectors.

\section{Author Contributions}

All authors contributed to data analysis, drafting or revising the article, have agreed on the journal to which the article will be submitted, gave final approval of the version to be published, and agree to be accountable for all aspects of the work.

\section{Disclosure}

The authors report that there are no conflicts of interest in this research.

\section{References}

1. Sterling JC. Human papillomavirus infections. In: Kang S, Amagi M, Bruckner AL, editors. Fitzpatrick's Dermatology in General Medicine, 9th. United States: Mc Graw Hill; 2019:3095-3196.

2. Mawardi P, Soenardi A, Karyosentono H, et al. Profile and risk factors of sexual transmitted infection among homosexual and transgender in Surakarta, Central Java. 6th International Conference on Public Health. Sebelas Maret University; 2019:114.
3. Gilson R, Nugent D, Werner RN, et al. 2019 IUSTI-Europe guideline for the management of anogenital warts. J Eur Acad Dermatol Venereol. 2020;34(8):1644-1653. doi:10.1111/jdv.16522

4. Chaturvedi AK, Madeleine MM, Biggar RJ, et al. Risk of human papillomavirus-associated cancers among persons with AIDS. $J$ Natl Cancer Inst. 2009;101(16):1120-1130. doi:10.1093/jnci/djp205

5. Conley LJ, Ellerbrock TV, Bush TJ, et al. HIV-1 infection and risk of vulvovaginal and perianal condylomata acuminata and intraepithelial neoplasia: a prospective cohort study. Lancet. 2002;359 (9301):108-113. doi:10.1016/S0140-6736(02)07368-3

6. Massad LS, Xie X, Darragh T, et al. Genital warts and vulvar intraepithelial neoplasia: natural history and effects of treatment and human immunodeficiency virus infection. Obstet Gynecol. 2011;118 (4):831. doi:10.1097/AOG.0b013e31821a0f4d

7. Sterling JC. Viral infections. In: Griffith CEM, Barker J, Bleiker T, editors. Rook's Textbook of Dermatology, 9th. London: Willey Blackwell; 2016:25.2-9.

8. Patel H, Wagner M, Singhal P, et al. Systematic review of the incidence and prevalence of genital warts. BMC Infect Dis. 2013;13 (1):1-14. doi:10.1186/1471-2334-13-39

9. Puspawati NMD, Sissy S, Gotama D. A retrospective study of condyloma acuminata profile in outpatient clinic of dermato-venereology Sanglah General Hospital Denpasar, Bali-Indonesia period 20152017. Bali Dermatol Venereol J. 2018;1:1-3. doi:10.15562/bdv. v1i1.1

10. de Peder LD, da Silva CM, Madeira HS, et al. Predictors associated with and the prevalence of condylomata acuminata infection among people in Southern Brazil. Health Sci J. 2011;11(1):22-30.

11. Piketty C, Darragh TM, Costa MD, et al. High prevalence of anal human papillomavirus infection and anal cancer precursors among HIV-infected persons in the absence of anal intercourse. Ann Inter Med. 2003;138(6):453-459. doi:10.7326/0003-4819-1386-200303180-00008

12. De Sousa JB, Duraes L. Human papilloma virus and anal cancer. In: Malla N, editor. Human Papillomavirus and Related Diseases-From Bench to Bedside-A Clinical Perspective. Kroasia: InTech; 2012:141-154.

13. Sharma N, Sharma S, Singhal C. A comparative study of liquid nitrogen cryotherapy as monotherapy versus in combination with podophyllin in the treatment of condyloma acuminata. J Clin Diagn Res. 2017;11(3):1-5.

14. Fathi R, Tsoukas MM. Genital warts and other HPV infections: established and novel therapies. Clin Dermatol. 2014;32 (2):299-306. doi:10.1016/j.clindermatol.2013.08.014

15. Blossom SJ, Pumford NR, Gilbert KM. Activation and attenuation of apoptosis of $\mathrm{CD} 4+\mathrm{T}$ cells following in vivo exposure to two common environmental toxicants, trichloroacetaldehyde hydrate and trichloroacetic acid. J Autoimmun. 2004;23(3):211-220. doi:10.1016/j. jaut.2004.06.007

16. Newell MK, Haughn LJ, Maroun CR, et al. Death of mature T cells by separate ligation of CD4 and the T-cell receptor for antigen. Nature. 1990;347(6290):286-289. doi:10.1038/347286a0

17. Barber EK, Dasgupta JD, Schlossman SF, et al. The CD4 and CD8 antigens are coupled to a protein-tyrosine kinase (p56lck) that phosphorylates the CD3 complex. Proc Natl Acad Sci. 1989;86 (9):3277-3281. doi:10.1073/pnas.86.9.3277

18. McCabe MJ, Whitekus MJ, Hyun J, et al. Inorganic mercury attenuates CD95-mediated apoptosis by interfering with formation of the death inducing signaling complex. Toxicol Appl Pharmacol. 2003;190(2):146-156. doi:10.1016/S0041-008X(03)00159-5

19. Cao JL, He YL, Zhang XY. The Relationship between HPV Infection and Cell-mediated Immunity in Patients with Condyloma Acuminatum. Chin J Dermatovenereol. 2012;1:5.

20. Shi YJ, Yang J, Yang W. Mechanistic investigation of immunosuppression in patients with condyloma acuminata. Mol Med Rep. 2013;8(2):480-486. doi:10.3892/mmr.2013.1511 
21. Singh M, Thakral D, Rishi N, et al. Functional characterization of CD4 and CD8 $\mathrm{T}$ cell responses among human papillomavirus infected patients with ano-genital warts. Virusdisease. 2017;28 (2):133-140. doi:10.1007/s13337-017-0382-8
22. Cao Y, Zhao J, Lei Z, et al. Local accumulation of FOXP3+ regulatory T cells: evidence for an immune evasion mechanism in patients with large condylomata acuminata. $J$ Immunol. 2008;180 (11):7681-7686. doi:10.4049/jimmunol.180.11.7681

\section{Publish your work in this journal}

Clinical, Cosmetic and Investigational Dermatology is an international, peer-reviewed, open access, online journal that focuses on the latest clinical and experimental research in all aspects of skin disease and cosmetic interventions. This journal is indexed on CAS.
The manuscript management system is completely online and includes a very quick and fair peer-review system, which is all easy to use. Visit http://www.dovepress.com/testimonials.php to read real quotes from published authors. 